\title{
THE MANAGEMENT OF BORDER AREA BETWEEN INDONESIA \\ REPUBLIC AND PAPUA NEW GUINEA IN SOTA REGION OF \\ MERAUKE DISTRICT
}

\author{
YOHANIS ENDES TETURAN* \\ SRI SUWITRI* \\ YACOB WARELLA* \\ HARDI WARSONO*
}

* Diponegoro University, Faculty of Social and Political Science, prodidap@ gmail.com

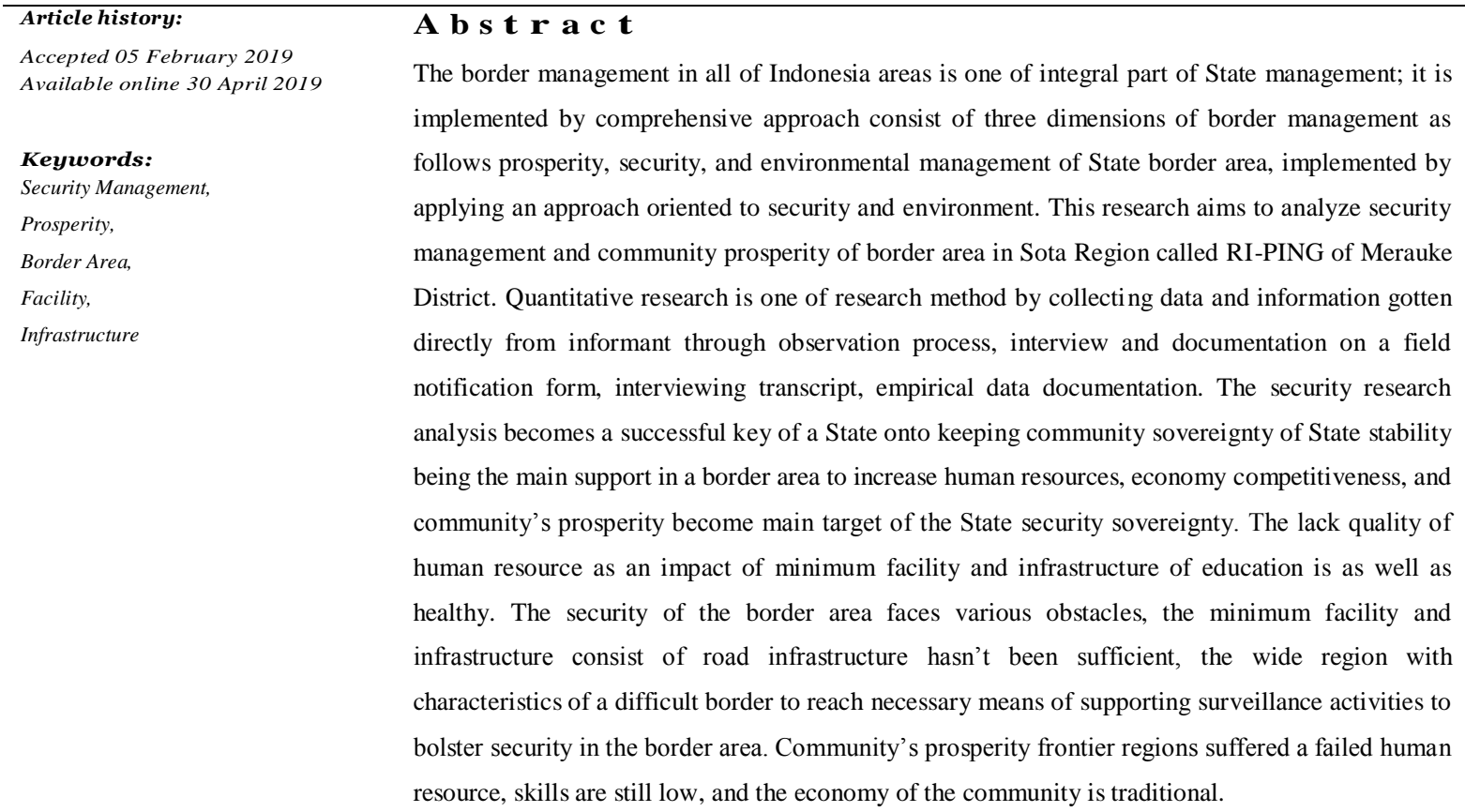

\section{Introduction}

The management of the border throughout Indonesia region is an integral part of the management of the State, the management of the border meant as border handling management activities. Understanding of the border, in a Grand Design 2011-2025, defined as the limit of the area of the country and the area of the border, so that the terminology "border management" need to constantly reads in terms of the management of borders and the border. In Indonesia 2008 was about the State territory, then the border management of an effort meant how to move people through the border area and potential assignment program planning. Drafting policy needs budget implementation, coordination, evaluation and supervision as well as over its handling of the country's borders and border regions to achieve the objectives as set out. Three approaches to the management of the border are as follows. 1) The management of the border done with three-dimensional approach in a comprehensive manner; 2) the welfare, safety, and environmental management of the country's borders and border regions, 3) carried out using an approach that is oriented on welfare, which is implemented in harmony with the other two approaches-oriented safety and the environment. 1) Dimension approach to Welfare (Prosperity Approach), is primarily the efforts made based on the 
development of economic and trade activities to improve the welfare of the community in the border area.

The development of economic and trade activities, directed towards flagship commodities based on each region's borders and beyond, according to different characteristics and potential quality. 2). Dimension approach to security (Security Approach), looked at the border area as a contiguous area directly with other countries. In addition, the territorial waters boundary role vital for the economy of many Nations because of being the path of world trade at once in it saves natural resources very large 3). Dimension approach to the environment, (Environment Approach) is looking at and paying attention to aspects of the environment as an important factor in the management of the border is important. In maintaining, the perspective of the sustainability of the environment and minimize the impact that will be caused by development activities in the border region into the gates of the economic activities and trade with neighboring countries. A fundamental problem in the border areas can be complicated and require extra attention from the Central Government or local governments and even the parties' corporate world.

This is because in addition to problems related to human resources, security and law enforcement, illegal trade, means of transport and infrastructure and the integrity of Indonesia, it also closely related to the well-being of communities in border areas. Broadly speaking, there are issues and problems that have emerged surrounding the Merauke- PNG border region can divide into several parts as follows.

\section{Table 1 The Strategy Issues and Urge into Developing Border Area of Papua- PNG}

\begin{tabular}{|c|c|c|}
\hline No & Strategy Issues and Urg & Problem Illustrations \\
\hline 1 & $\begin{array}{l}\text { The lack of Human } \\
\text { Resource Quality }\end{array}$ & $\begin{array}{l}\text { till low, the human resources (HR) quality in the border region has become a strategic issue/problem that } \\
\text { eeds urgent attention from the Government, because the level of quality of human resources available will } \\
\text { e the deciding factor in an attempt an increase in the well-being of its community. }\end{array}$ \\
\hline 2 & $\begin{array}{l}\text { Escaping area of the } \\
\text { outlaw }\end{array}$ & $\begin{array}{l}\text { Still lack the number of Defense and security apparatus coupled with the responsibility of a disproportionate } \\
\text { area became one of the causes of the low level of enforcement of the la. In addition to social conditions in } \\
\text { PNG effects on area crime in high numbers of the border. Due to excellent transport, access is still difficult, } \\
\text { and then the border area became a safe haven for the perpetrators of endeared/criminal (crime) in both } \\
\text { countries. }\end{array}$ \\
\hline
\end{tabular}

3 The illegal Limit passer In the past many citizens of Indonesia into PNG for political reasons, they now are not acceptable any more, to PNG \& reluctantly though not much. Gradually they began to return to Indonesia

returned to Indonesia Republic

\footnotetext{
4 Illegal trading

Due to the lack of existing infrastructure at the border, including the means of transport and has resulted in the obstacle line of the economy and distribution of goods/services toward the border area. Otherwise the distribution of relatively is easier with PNG, supported by adequate means. Due to the lack is a circulation of goods/products derived from PNG that does not come with document government (illegal trading).

$5 \quad$ There are still customary rights (Customs)

The Treaty of the colonial Government which splits into two regions of New Guinea (Indonesia and PNG), performed by pulling straight lines are astronomical, without looking at the existing socio-cultural conditions, a result is ownership/property (land, gardens) according to the right customary society asunder, there in Indonesia Republic and there is in PNG format. For this, it does serious handling. For example, claims for damages against the community land for mining, is actually finished, but the local community continued demand again.
}

6 PNG residents living in The lack of transportation facilities and infrastructure to the area of the border makes access from the Central INDONESIA territory Government of INDONESIA be very restricted, but other sided access to the PNG government easier. As the of, and vice versa results, there is somewhere the Government of PNG running effectively in Indonesia Republic. Because the PNG government is running, then the population claiming to be citizens of PNG though resided in the territory of INDONESIA.

7 Having 2 identity cards Economic and trade activities of illegal trading in the border area of languid, this has attracted the attention namely (KTP) double$\mathrm{RI}$ and $\mathrm{PNG}$ of the citizens who live in the two areas that border to conduct trading activity in the area, or between countries. With so many residents who live on the border, have 2 ID cards $(K T P) \& 2$ citizenships (Indonesia and PNG). 
$\begin{array}{ll}8 \text { Boundary (limits) } & \text { The border at RI-PNG, which is extends from Northern Skouw, stretching to the South until Bensbach River } \\ \text { between citizens of the } & \text { estuary. Geography and topography conditions quite difficult traversed less attention from the Government, } \\ \text { Indonesia Republic- PNG } & \text { especially against the existence of the boundary (limits) between countries where is very inadequate. }\end{array}$

9 The auction and Illegal trafficking (illegal trading) \& considerable market potential in the border area, demanding the traditional markets at Government to undertake measures towards a constructive policy, problems of trade and other economic the border activities, in order to society can legitimately be active (legal) \& regularly.

10 The Road Network (Infrastructure Area)

a) Very limited cross-border road network in Merauke, Jayapura, Boven, Digoel, Keerom, dan Pegunungan Bintang, the lesser Papuan trans Chain is adequate, the badly damaged road conditions

b) Network of centers-production center and primary productive are areas of plantations and Agriculture (rice, rubber, cocoa, coconut, etc.)

11 Illegal Lugging

Rampant illegal logging, a result of the resource management in particular forest resource done by the Community border, is extremely detrimental to good government or other community. Besides the destruction of forest as a source of major community, life also adversely affected by loss of income from the forestry sector estimate at us reached 600 billion in a year from the forestry sector.

12 Spatial Border Region In the border region development plan pays attention to spatial rule, this is because a good spatial locality or area border is paying in any planning come within the border of the future. Spatial as paying plans covers various aspects, among others; social aspects, economic aspects, political aspects, cultural and social aspects, including planning against small islands, particularly in the border region between Governments should not overlook. Small islands are particularly vulnerable to geopolitical and security issues (the separatist disturbance) many of which run into the smaller islands, as well as the problem of social, economic, and cultural, because the purlieus must get priority handling the Government comprehensively.

13 Infrastructure and 1. The limited means of the community's basic necessity (water, electricity, and telecommunications) and settlement transportation (roads, village markets, boat tethers village)

2. Housing in the area of border management, garbage, the need for the access road out towards the road existence of Kasibua and Lisibia, in Boven Digoel Region

14 Wasur National Park Management
The pattern of natural resources utilization in particular for border regions, which have a typology of protected areas and conservation, must have a pattern of resource utilization that pays attention to environmental sustainability and ecosystem. Wasur National Park forest damage would have resulted in damage to natural ecosystems, loss of biodiversity, and the potential loss of a source of income from the area's natural forest tourism sector of Wasur National Park. In addition to note an increase in the well-being of the communities in Wasur National Park and vicinity

\section{Source:https://www.google.co.id/?gws rd=cr,ssl\&ei=q0RgV4KC4yAvwTvvJCYCg\#q=isupembangunan+perbatasan+Papua+dan+PNG. \\ Accessed in March 22, 2016 in the development of Border Regions of New Guinea-PNG border region has become a strategic issue/problem that needs attention}

Public understanding is a significant number of human beings who have the same thinking, feelings, expectations, attitudes and actions that are right and good based on the values of the norm they have (Pratikno 2007). Public administration, according to (Keban 2004) was the process by which the resources and personnel of the public organized and coordinated to formulate, implement, and manage (manage) the decisions in public policy. While (Keban 2004) stated that the term public administration showed how the Government acts as a single agent in power or as a regulator, an active and always take the initiative in organizing or taking steps and initiatives, which. According to their importance or good for the public, because it assumed that the community is a party that is passive, less capable, and should be subject to and accept anything that set by the Government.
The Administration theory describes efforts to define universal functions carried out by the direction and principles that constitute a good leadership practices. (Henry 2012) stated that by using the approach top management administration, namely an approach from the top to the bottom level of the leadership. (Henry 2012) classified to three large donations for the Administration and management, namely (a) the activities of the Organization, (b) the functions or duties of the leadership, (c) the principles of administration or management.

\section{Literature Review}

\section{A. Supporting Factor of Border Management}

The border region is a strategic area in maintaining the territorial integrity of the State, then the necessary management 
specifically. The management of the country's borders and the border needed to provide legal certainty regarding the scope of the country area. The border area became an important supporting factor in either always be discourse on border area is as follows.

1. There is no national policy and strategy development of the border area can be a reference for a variety programs and activities.

2. Approach to security is more prominent than a welfare approach, as it demands in the past. While it indeed much going revolt around the area of the border.

3. Handling the border is still partial and ad hoc so not optimal.

4. There has been no coordination between agenciesrelated institutions at the level of the regions and the Center.

5. Communities on the border of generally is poor because the accumulation of several factors, namely the low quality of human resources, the lack of supporting infrastructure, low productivity of society and yet optimal utilization of natural resources.

6. The number of the door borders (cross-border postal inspectors and postal cross-border) is still very limited, thus reducing the chances of an increase in social and economic relations between the neighboring countries with Indonesia.

7. Access to land and sea border area is very inadequate and the means of communication is very limited, so that the orientation of the community tends to neighboring countries. This condition can cause a degradation of the nationalism of the Community frontier.

8. The basic social and economic Means are very limited. Because of the population in the border area trying to obtain social services and try to filfill the necessity of its economy to the area of the border neighbors.

9. The authority handling the region still widely issued government agencies at the Center.

10. The coordinate's border management does not complete on the agency at the national level and the regional area.

11. Management of natural resources is not optimal and future-oriented.
12. Lack of infrastructure security and defense apparatus activity causes security and defense on the border is not yet optimal. Surveillance along the border of the continent as well as maritime is also weak, so frequent transgression of the boundaries of the country by the people of both countries.

13. There are regional demands to manage the border area along with the introduction of decentralized and autonomous region. They are demanding revenue from cross border Supervisory Post can be one of income for local governments.

14. There is a considerable investment bid, but stuck to the limited funds the construction of facilities and infrastructure provided the Government and the local government.

\section{B. The Barrier Factor of Border Management}

Indonesia's strategic geographical location has the potential threat of the future will be more complex. Meanwhile, on the other hand national security stability has not been strong. Indonesia is still experiencing periods of transition and consolidation (political, economic, social, cultural, security and defense) towards a democratic State. The form of the threat to State sovereignty's happening currently are making a multi-dimensional progress along with the development of science, technology, information, communication, and therefore the whole nation of Indonesia is required to overcome any threats, challenges, barriers, and interference, whether it comes from within and outside the country. The sovereignty and integrity of price is so dead, so the effort to keep the country intact and sovereign becomes very important. This article will aim to analyze what factors and how the role of the key factors in maintaining national defense.

1. The potential intervention of foreign culture and ideology;

2. Human trafficking, especially women and children;

3. Socio-cultural conflict

4. Stretch the area of the border is between the Indonesia Republic with 10 neighboring countries is extensive and varied, ranging from the study of type inland up the type of the outermost islands. This resulted in a range of control and handling border region face challenges and obstacles that are heavy, both in the provision of the resources of the Fund as well as humans.

5. Weak enforcement of the law against thieves, smugglers of goods, the sale of human beings, and 
piracy, smuggling of arms, smuggling of human beings as well as the theft of fish.

6. There is a difference in the level of well-being with neighboring countries such as Malaysia.

7. There is no legal certainty for the principals of development, so there is no base footing for the perpetrators of the development in the area of the border.

8. Weak enforcement of the law against the thieves' wood (illegal logging), a smuggler of goods, human trafficking, hijacking and piracy, smuggling of arms, smuggling of human beings (such as labor, the baby, and women), as well as the theft of fish.

9. Natural resource exploitation occurs in unrestrained due to weak law enforcement.

10. Lack of infrastructure security and defense apparatus activity causes security and defense on the border is not yet optimal. Surveillance along the border of the continent as well as maritime is also weak, so frequent transgression of the boundaries of the country by the people of both countries.

11. Problems with neighboring countries, among others, have not been clearly and firmly continent and maritime boundary line; How to deal with the anglers of both countries in violation of the territory of the country; and there is the traditional boundary of the passer due to kinship, culture and customs of the similarity of the two countries.

12. The problem of the development of the area along the border, because the authority is the management central government permission must be seen and a very limited funds.

According to (Guo 2015) stated that the border or boundary refers to limiting an area of definition and political living spaces it has a broader meaning in political issues and economic geography of the frontier although both usually refers to cases particularly from the border boundary to divide the sovereignty of independent States. Whereas the area of borders is commonly known as the space geography remains and is close to the border line in the socio-economic effect is significant due to the limit.

Simply put, the boundary defined as a legal-political unit, which has various functions of the unit for a country. As stated by (Wuryandari et al. 2017) and (Blanchard 2018) in the context of such understanding, borders had a wide range of functions. It includes as follows: (1) the functions of military defense; (2) economic function; (3) the constitutive function (4) the functions of the national identity; (5) the functions of National Unity (6) function of the development of the nation State and (7) the function achievement of democratic interests. Although dominated by realism, an approach that emphasizes on the interests of the State, not the individual, but also incorporate the concept of the Blanchard economic, social and cultural aspects in the management of the border.

These seven functions in this conceptual by Blanchard, requiring the involvement of the various elements in the country as the military, police, civilian officials, and the general public, especially the residents around the border in the management of the border. Defense function of course is the dominant forces of the AIR FORCE; economics functions run by economists (merchants, farmers, and policy makers at the national level as well as at the regional level). Constitutive function is the task of the police, immigration officers and law and Government apparatus areas; the function of national identity involves all of the above as well as the officers with the public, especially the border areas. The function of national unity is part of the Central Government and the regions and security apparatus (TNI and Polri); the function of the nation State and its construction is the duty of all parties referred to above, including the citizens of the community. While the domestic interests of the achievement function, are the policy makers of the border officer, in this case the Central Government, which exercised by the Government landscape?

(Mann 2013), stated that the elements of the State should protected consists of four important things, are as follows. (1) ideology, how to seek protection against State ideology from possible infiltration of State ideology; (2) how the economy maintaining continuity of economic activity in the territory of a State not to bothered by the forces (external or internal) in-time damaging the national economy. (3) how the military defend the sovereignty and integrity of the country from various threats (mainly external forces), and (4) political, that is how to maintain the political identity and unity of the State and the nation from a variety threat both of external as well as internal.

(Indonesia 2008) about the country area, distinguish the borders into the country's territorial boundaries and the area of the border. The boundaries of the country are the boundary line is the separation of the sovereignty of a country, which based upon international law. Whereas the area of borders was, a part of the territory of a country located on the side of Indonesia in all areas with other countries, in this case the territorial boundaries of countries in different border areas by land, in town to face directly with neighboring countries. The area of the border according to (UU No.27 2007) and (PU 2008) is a District/ City territory geographically and demography bordering the neighboring 
country and or the high seas. (Tirtosudarmo 2005), citing (Ricklefs 2015), mentioned that the border of the country of what is now Indonesia built by the colonial military forces (Netherlands). at the expense of human lives, money, destruction of the environment, separated bonds social and overturning the dignity and human freedom (in (Wahyuni, Ardhana, and Sunarta 2008): more (Gutierrez and Martinez 2006) cited by (Tirtosudarmo 2005) theorizes that there are four types of border as follows:

1. Alienated Borderland: a border region that is not the case, cross-border activity because of the war condition, conflict, and domination of nationalism, the ideological hatred, and hostility to religion, cultural differences and ethnic rivalries

2. Coexistent Borderland; a border region where regular cross-border conflict is suppressed to the level which can be controlled though unresolved issues that arise for example with regard to the issue of the ownership of strategic resources at the border.

3. Independent borderland; a region on both sides of the border are symbolically linked by a relatively stable international relation. The second part of the population in the border area, also in the two countries are engaged in various activities mutually beneficial economy and more or less in an equivalent level, for example, one party has production facilities while others having the cheap labor.

4. Integrated Borderland; a border region that economic activity is an ebbing away of nationalism, unity in both countries and both of them joined in the close Alliance.

Management is the process of how power moves the support is there to meet the necessity and the problems of effectively and efficiently according to the purpose. Tasbara, showed on the activity "across the dividing between the two neighborly countries" with a set of rules of international law and the agreement of the two countries. Thus, the power support border in order to embody trip and control over the needs and problems of the country as a region boundary crosser often appropriate and effective rule of law and the agreement of the two countries were neighbors (Sumarsono 2004)

(Ullman, Jones, and Boggs 2006), in a book entitled Boundary Making: A Handbook for Statesmen, Treaty Editors, and Boundary Commissioners, formulating a theory related to the management of the border. In theory, Jones split scope management into four parts, namely: Allocation, Delimitation,
Demarcation, Admin/Management specific to the scope of the fourth part (administration), the development has shifted towards the border management or management of such scope to four interlinked to each other, signaling to these fourth are series of interrelated decision-making in practice. Theoretically, the management of the border is composed of four (4) phases, namely the Allocation, Delimitation (determination of limits), Demarcation (enforcement of limits), and Administration (management development) Image as shown below. Allocation phase, collies, and democracy more related aspect is the management boundary area of the country (boundary line). While the administration more related stages in development activities in the border area (boundary area).

Figure 1: these four models of Boundary Making Theory

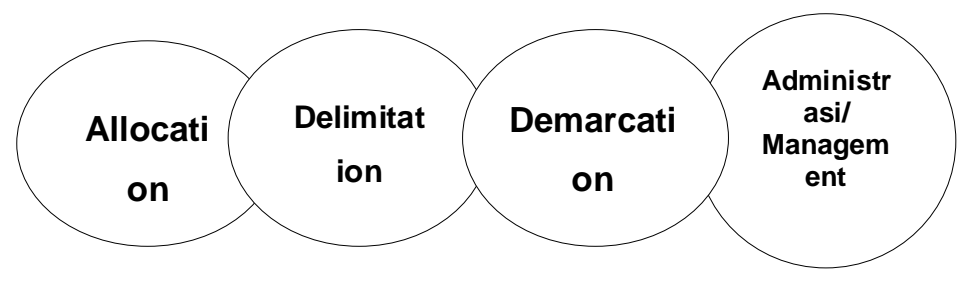

Source: (Ullman, Jones, and Boggs 2006)

Allocation (Allocation) defined as an area of coverage of the countries, including the where areas bordering neighboring countries. Subject coverage of the region, then in the international law, has regulated on how real a country gain or loss. Related to Indonesia, then the scope the entire territory of Indonesia territory inherited from the Netherlands. This is in accordance with the principle of Uti Possidetis Juris International law, which States that a State inherited the ruler of invader. (b) The determination limits (Delimitation) after coverage area known, the next step is to identify the areas of agricultural areas overlapping or limit should specify with the neighboring countries. As one example of the overlapping region is the fact that the width of the Strait of Singapore did not reach 24 nautical miles, while UNCLOS entitles the States parties to be able to have as wide a territorial sea of 12 nautical miles.

Due to overlapping claims wide sea area between coastal States around the Strait of Singapore, then in accordance with the (UN 1982), Coastal States must do negotiation borders between the two countries. To limit the jurisdiction of the sea, according to ("Code of Conduct for Responsible Fisheries" 2012) set also the need for negotiations between countries that limits assignment have overlapping claims. Related to the determination of the limits of State land, the negotiations also became the way that taken by the bordering countries. (c) Affirmation of the limit (Demarcation) or boundary of the affirmation in the field is the next stage after the boundary line fixed by the State Government that the mutual borders. As already mentioned above, in a Treaty 
limits, in addition to the mentioned point coordinates the use of the point limit, attach a map illustration of an agreed boundary line. Due to the nature of the boundary line, which is very important, as a marker to start and end the rights and obligations of a country, then the layout would have been in the field need defined. This done by installing a sign of use of the sign boundary along the lines of the limits enforced.

Associated with the context of the maritime border, the affirmation of the boundaries by using boundary marks in the middle of the sea is an uncommon thing to do. However, this does not cover the possibility (if necessary) to put the sound of buoyancy (buoy) limits or as a marker of both countries conduct a joint survey of the boundary mapping. (d) Administration/Management Development in the management of the border area is good according to the theory of boundary making, Administration/management development borders can be implemented are overlapping with the demarcation. It is based on consideration in fact often faced obstacles and dynamics that occur in the field concerning the aspects of economic, social, cultural and political.

So often done in segmentation, and administration/management activities go hand in hand with the implementation affirmation of the limit field. Because this step is part of the follow-up of the separation of rights and obligations are between countries due to the appearance of the border region. Within the scope of the Administration and management of development, the volume of work in handling the most borders, because it involves the use of multi-sector and integrated planning is required. Almost all aspects of construction, from the aspects of the political, economic, social, cultural, legal, infrastructure, the environment, defense and security would exist at this stage. From the side of the bilateral, both bordering countries are very common to conduct cooperation in various sectors.

The border has a military-strategic functions, constitutive, identity, national unity, national development and domestic interests. (Brunet-Jailly 2017) explained that border management should give attention to the four elements of border security as follows:

1) Influence of political factors in communities in the border region. Musty covers the extent to which local actors give it influence in determining the border between the governance of the country.

2) Government policies of countries bordered it. This aspect is concerning horizontal relations (between government agency equivalents) and vertical (between government agencies with the hierarchy of the different authorities; central, provincial, district/city, sub-district, and village/region).
Horizontal relationships appear to characterize the nature of governance multi-level governance such as European Union and ASEAN in the setting of policy joint immigration (visas, passports, and others). Meanwhile the vertical becomes relationship characteristic of policy arranged bilaterally, between the two bordering countries directly.

3) Market forces and trade flows. This aspect is very important for the selection of the governance of the border because of concerns the economic function of the border. Countries that give priority to free market, usually encourages the opening of Selonggar border might be in order to support market forces and encourage trade flows between countries.

4) Typical Culture Community is at the border. The typical culture of the musty belonging to communities in the border region also refers to what by (Brunet-Jailly 2017) called the local context. Market forces and trade flows. This aspect is very important for the governance selection of the border because of concerns the economic function at border. Countries that give priority to free market, usually encourages the opening at Selonggar border might be in order to support market forces and encourage trade flows between countries.

Figure 2: Border Management Model

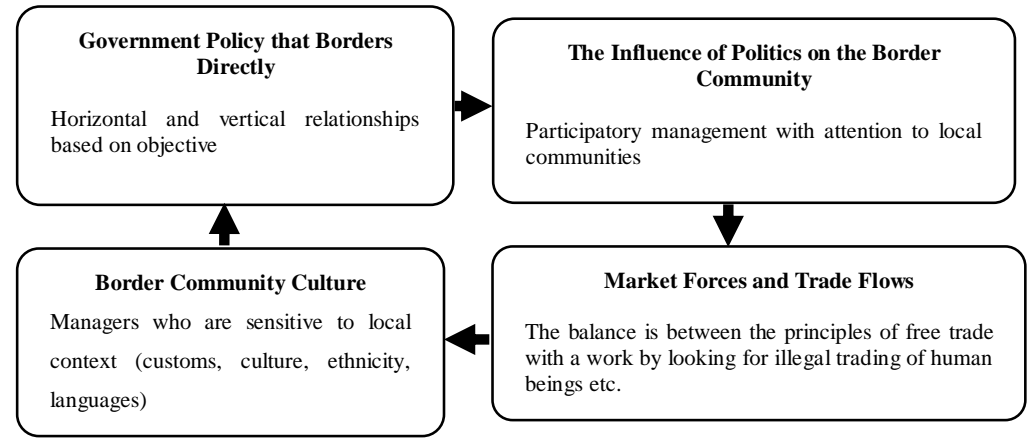

Source: (Brunet-Jailly 2017)

The fourth element of the governance of the border above has an important value, which can used as a base in an attempt to find patterns of managing border security on the border with Indonesia. The determination of whether the border should open (soft border) or closed (hard border) is a challenge of its own. As mentioned, consideration of free trade could not fully used as a reason to open the border because of the existence of mere trade. Thus, the State should be required to more or less closes the 
border to minimize the existence of security threats, both of which are traditional (military strategy) as well as non-traditional (drug trafficking, human trafficking, smuggling and others). Thus, though the border needs opened to ensure smooth traffic, but also the need to limit the levels of openness based on security considerations.

Then, in globalization era, even the border still have important meanings, as it is said (Helliwell 2000): "despite some economic integration, borders continue to ' matter ' because they not only delineate the boundary of governments but also bound the social networks and most human interaction. In addition, the internal situation of the country as is said to Jean-Marc Blanchard also determines the formation of the inter-State border governance. For countries that enter into what made by Blanchard categorized as low states, i.e. a country experiencing a legitimacy crisis is acute, the absence of security politics, inflexible pieces and order, weak security apparatus, a lack an adequate military force to defend the country. It is a priority in the management of the border is (1) maximize the security in the country, (2) reduce the bad influences from the outside (3) prevent citizens to escape out of the country, and (4) optimize the border to protect the country's development efforts and the nation. (Brunet-Jailly 2017)

\section{Research Method}

Analyze the management of the security and welfare of the Community area of the border district of Sota RI-PNG in Merauke District. Research is an in-depth observation to discover, understand and test as well as analyze something particular objects with the methodical ways or using the scientific method. Methods the study according to (Silalahi 2010) the chosen Research Methods is a very important part and formed a success whether a research. The research method is the guide of researchers in conducting research. Symptoms of an object examined objectively and formulated rational and systematic way with research methods. To ensure discovery of scientific truth, the method that gives the precise workings and requirements are very strict. Thus means the research method not only provides an opportunity as big as for the discovery of the truth objectively, but also so that knowledge and its development have a high scientific value.

Methods of collecting data is quantitative i.e. data that is expressed in the form of numbers. While qualitative data expressed in the form of words, sentences, and images. The primary data-that is, the data and information obtained directly from the informant through the process of observation, interview and through the process of documentation in the form of field notes, transcripts of interviews, documents other empirical data.
The coordination strengthens the data (data validation). Condense data is part of the analysis of the data, in the form of analyses that sharpen and set data types, focusing and eliminating data in such a way in order it can finally verified and drawn conclusions. The second main stage of the analysis is the presentation of data. In general, the presentation of data is a process of organizing, assembling and consolidation of information that allows the conclusion and withdrawal activity. The form of presentation of the data that would use is a form of narrative texts.

With the consideration, that any data that appears is always closely related to other data, then the expected any data understood and is inseparable from the setting. The presentation data used to interpret and take summary (inference) which is the meaning of the data collected in order to answer the problem. The last stages in the model analysis of this data are interesting summary and verification. Summary in question is the definition of the data that has collected. Observation taken is gradually such as. First, drawing up summary is while (tentative), but with the increase of the data, it is necessary to do the verification data i.e. relearn existing data and conduct peer-briefings with experts so that the data obtained are more precise and objective, both pull the knot the end. Summary of withdrawal carried out by comparing the way of statement agjusment of respondents with the meaning contained in the research issues conceptually. Secondary data is data already available at government agencies or social institutions associated with it. The data in the form of references, documents, guidelines for implementation of the program, reports the results of research and scientific writing are used to support this research, including: Data about the description of the location of the research, and about the condition Geography (broad and geographical location as well as climate), population, economic, socio-cultural circumstances (facility and infrastructure).

Data collection techniques in the research observation, it implemented through interviews, documentation and studies. In the process of collecting data, humane approach between researchers and data source becomes the main instrument in this study. Observation is a deep observation activity against the phenomenon and real events that happened in the field directly relevant to the issue of the prosperity management, the area of the border district of the Indonesia Republic between Sota -PNG in Merauke District. In-depth interviews (in-depth interview), this kind of interview techniques implemented with all informants to obtain primary data. This interview was conducted with information in a depth manner was directly involved with the lives of informants for free by using the guidelines of the questions beforehand so that the atmosphere is lively and done many times. Study documentation is done in full, complete and intact to enrich research data through documents such as reports, regulations, instructions, treatise meeting, decision letters as well 
as earlier research, and available on the agencies to obtain data from various parties.

The selection of informants are the ones that are on the scope of research, and able to provide information on the situation and conditions of research. The informant is a person who represents the unit of analysis to obtain data accurately and representative, then at need informants to understand and related to the research that examined. Data collection with an in-depth interview technique, observation and study of the documentation done by specifying the appropriate informants in research and represents the unit of analysis. Thus, the informants in this study are:

Table 1. Research Informant Selection

\begin{tabular}{llll}
\hline No & \multicolumn{1}{c}{ Main Informants } & Tranquilization Informants & Supporting Informants \\
\hline \multirow{2}{*}{$\begin{array}{l}\text { Regional Tourism Promotion Agency } \\
\text { of Merauke District }\end{array}$} & Customary/Religious Figures & District Head of Sota \\
\hline 2 & $\begin{array}{l}\text { Regional officials who know about } \\
\text { border issues in Merauke }\end{array}$ & Community Group & Koramil of Sota \\
\cline { 3 - 4 } & District Head of Sota & Polsek of Sota \\
\cline { 3 - 4 } & & $>$ Sota's Immigration \\
\hline
\end{tabular}

Source: managed to research necessity, 2016

\section{Result and Discussion}

\section{- Security Management Term (Security Approach) of The Border Area}

Safety factor (Security Approach) is the territory of the region of the border became a top priority in order to maintain the unitary State of the Indonesia Republic with neighboring Papua New Guinea. Security became the key to the success of a country in maintaining the sovereignty of the nation security stability so the cantilever major border areas for the improvement of human resources, economic competitiveness, and the welfare of the citizens of the community are the main objective in maintaining the security of the State. The increasing of human resources in Sota District and potential development in the framework of the flagship as well as improvement of the economy and the welfare of the citizens in border area. For it is the role of citizens in cooperation with The INDONESIAN ARMY FORCES in maintaining the security of the border region in the framework of the unitary State of the Indonesia Republic intact and Papua New Guinea.

Traditionally there should be a wide range of services and agencies involved in the implementation of the border control and various inspections take place at the border. The border area of Sota District in domination by the border security forces stationed along the border starting from Elikobel District up to Sota District,. this indicates that the border in Merauke with the PNG security approach more dominant against a welfare approach (Prosperity Approach) and the approach of the environment (Environment Approach) in the area of the border district. The border intepreted were according to (Hersey and Blanchard 1996) in (Ulfa, Fimmastuti, and Nia Rahmah 2018). In the context of the understanding of the border has a function in a variety of functions; military defense function, economic function, the constitutive function, national identity function, national unity function, development country function as well as nation and the achievement of democratic interests. Occurring functions of defense and security is the responsibility of the Air Force to keep the border, whereas the social economic function should give a role to the community so that it can function implemented as well as divisions facilitate oversight, while the function of national unity given a role to the Central Government and the Government landscape.

Preferred security approaches of the border region so that the welfare of the citizens of the community and the environment neglected, so that the management of social welfare has always worked in the area of the border issue so that needs described. individual commandments themselves problem occurs, it is brought to the attention of the Central Government and local governments in formulating policies and program plans are right on target so that it can deliver benefits to the citizens of the community who live in area the border of Sota District. These benefits need facilitated with a wide range of program activities that could bring the impact of the change to the citizens of the community itself.

\section{- Prosperity Management Term (Prosperity Approach) in The Border Area}

Management welfare of the border region in order to fulfill the community necessity by looking at various issues that always haunts the lives of those in the district border area will certainly have an impact in maintaining the security and order the border region with neighboring country of Papua New Guinea. Because welfare is very important thing is concerned with the life of the 
community itself, as synonymous with wellbeing poverty constant affects the lives of citizens in the area of the border. It need identified the community necessity and excellence in the border area easier to map necessity and program activity that is the basis for solving the problems faced by the community. So that the needs of the community can filled as well as encourage developing potential flagship premises that made to community needs so easily at the push to accelerate economic growth in the border area.

It is very important to boost the economy of the border be developed and can be utilized as a potential flagship border area. The border area has always categorized as the poorest regions underdeveloped; it is already a public consumption towards the welfare of the people living in the border area. The border area remains underdeveloped and becomes a reflection for the people of Indonesia with neighboring countries, according to (Andrinof A. Chaniago 2015) of Nawa Cita President and Vice President to create the program priority of its rule for 5 (five) years called with Nawa Cita or 9 Program priorities. The ninth priority programs have been listed on the agenda of priority development (Andrinof A. Chaniago 2015) 2015-2019. This program initiated to indicate priority roads changes towards a sovereign Indonesia politically, as well as independent in the field of Economics and personality in culture. Called Nawa Cita, at three points called "building of Indonesia by strengthening suburban areas and villages in the framework of the unitary State".

There are aspects of the management of the State border is thick enough, which means that during the next five years, the management of the State border is given more attention. As for the important points referred to in priority to these, three in Nawa Cita Goals are as follows. The laying is foundations of the start of Decentralization Asymmetrical. Development starts with the need to put the basics of asymmetrical decentralization policy by implementing the policy alignments (affirmative policy) to the areas, which are still notably lags. (a) The area of the border and outlying islands; (b) the area left behind and isolated; (c) the village left behind; (d) the areas that Government has not been adequate capacity in providing public services.

Development approach consists in: (i) the approach of security (security approach), and (ii) the approach of increasing the welfare of society (prosperity approach), which focused on the 10 national strategic Activities Center (PKSN) and 187 Sub Location Priority in 41 Counties/cities and 13 provinces. Equitable development is between regions especially village, eastern Indonesia; The development of economic growth centers (PKSN) in the framework of equitable development between regions, with the goal of reducing the gap between regions and social disparities. Poverty reduction: a comprehensive social protection Policy in order to make the people less able to secure fulfillment of its necessity, it is especially the Ministry of health and the need for Staples, in the event of an economic shock or shocks social happening. Provisioning is against the underprivileged and vulnerable residents in the form of entrepreneurial skills as well as technical skills to enhance their competitiveness in the productive economic activities. Poverty reduction development of border areas development starts from the border because the border area of the welfare of the community during these lagging compared to other areas. Inequality of development and development results illustrate the magnitude of the still poverty and vulnerability. Objectives is to realize the construction of the poverty reduction that enjoyed by all occupations.

\section{- Prosperity Management Term}

The low quality of human resources because of the lack of infrastructure and facilities in the field of education and health care, resulted in the quality of the human resources community in large areas of the border are still low. The society has not acquired the services of health and education, as they should due to distance from settlements with the existing facilities. The border region security approaches are more prominent than on the welfare of the Community approach to the economic development in the border areas will be hard to do because the economy is still traditional in nature. Low levels of education, skills and health of the community is one of the main factors that hinder the economic development of border regions to be able to compete with the country's neighbors. Utilization of the resource so that it is able to optimize the potential of natural resources so that it can be used by residents of the border area.

\section{- Security Supporting Factor of the Border Area}

Nothing availability of means of defense and security-level battalions are in the county border. In anticipation of the era of globalization and the opening of international access in various sectors are especially regarding defense and security. Merauke Regency which has an interstate border area is still very vulnerable to breakaway disorders and other possible criminal actions led to the international issue would be detrimental the nation of Indonesia. It therefore deemed important to construct facilities of defense and security adequately both in terms of physical as well as the band's style. (Gunawan 2017) in a study analyzing about "Indonesia a boundary line management effort to ensure the security of citizens" security sector reform discourse is often addressed only on the reform of security actors i.e. Military, Police, and Intelligence. On the reform of the security sector is creating a security architecture that provides security to citizens of Indonesia as a whole within a framework of democratic supervision. Do reformation security sector not only mean 
reforming the roles, functions, status and control over the security sector actors, but also the synergize capabilities of the national security and defense systems that exist with threats security globally.

The defense of State security might clarify in Legislation of Indonesia Republic No. 3 in 2002 about the Defense of Country. In chapter III the Organization of Defense of Country article 7 (1) the defense of the State, as stipulated in article 6 , organized by the Government and prepared early with the defense system of the country. (2) State Defense system in the face of military threat puts Indonesia national army as the main component supported by the backup components and supporting components. (3) State Defense system in the face of threats nonmilitary put government agencies outside of the field of Defense as the main element, according to the form and nature of the threat faced by supported other elements of the nation power. It explained that security defense with a variety threats and the development of information technology is a very rapidly in the current globalization era, it should Security Defense function is always alert to the situation and condition occuring. The multidimensional nature of the threats that can be sourced, from either the problems of ideological, political, economic, cultural or social security issues associated with international crimes, including terrorism, illegal immigrants, the danger Narcotics, theft of natural resources, pirates, and destruction of the environment.

The availability of human resources becomes essential to drive the wheels of the community economy in managing natural resources. (Campbell and Terry 2006) in (Effendi 2006) argued that management is a process that consists of typical actions planning, organizing, direction, and control are conducted to determine and achieve the target that have been determined through the utilization of human resources and other resources. Human resources have a very important role to determine the organizational planning is going well, as well as control any activities that have done so that it could achieved. In addition to human resources also required other resources to support the achievement objectives of the Organization, a process that is in want.

Merauke Regency has the widest farmland in Papua Province. In addition, local governments are promoting government programs to improve agricultural production in order to Merauke could become the "National Granary". The rice production of Merauke Region in 2015 amounting to $153,661.09$ tons with a total area of $32,516.88 \mathrm{Ha}$ and crop productivity amount 4.73 tons/Ha. Compared with the previous year, acreage, harvest, and the production of rice in Merauke Region declined (Eben E. Siadari 27AD). Continuity to strive for increased productivity so that farmers are able to encourage increased economic of agriculture sector, this indicates that the Government keep trying to Merauke Region could supply rice in Southern New Guinea in Merauke Region of PNG country bordering also the Asia Pacific area.

Table 2 Extensive Harvesting, Production and Productivity of Rice and Vegetable In Merauke Region 2015

\begin{tabular}{llll}
\hline Productions (Ton) & Vast Area (Ha) & Productions (Ton) & Productivity (Ton/Ha) \\
\hline Rice & $32.516,88$ & $153.661,09$ & 4,73 \\
\hline Corn & 370,00 & $1.110,20$ & 3,00 \\
\hline Soybean & 645,00 & 774,10 & 1,20 \\
\hline Peanuts & 354 & 710 & 2 \\
\hline Green Beans & 88,00 & 153,70 & 20 \\
\hline Cassavas & 407 & 7.977 & 12,02 \\
\hline Sweet Potatoes & 558,00 & $6.708,20$ & \\
\hline
\end{tabular}

Source: (Eben E. Siadari 27AD)

\section{Restricting Factors Management of Border Area}

Based on data collected from (Bappenas 2006), the number of violations of territorial boundaries well done by citizens as well as citizens of Indonesia Republic-PNG caused confuses the PIN State boundaries. The length of the boundary lines of Indonesia
Republic-PNG Papua about 760 kilometers and a pillar of the limit of 52 pieces, so that the distance between two adjoining boundary pillars reach over 14 kilometers. The distance between the two pillars of the limits far enough it becomes difficult to distinguish the area both of countries. These conditions make the boundary violations committed by both the citizens of the 
Indonesia Republic of as well as PNG citizens is very likely a violation this implemented accidentally. However, it is indeed very difficult to not do violation of boundaries between countries with the number of the boundary pillar is still very limited and very difficult topographic conditions.

The development of human resources quality of border regions is as a whole indeed very low due to various factors, among others, the influence of the environment of the community, the awareness of the community is still lacking. The economic factor family bandwagon effect and various other factors that directly impact the development of the border areas, the Human Resource community access to education is still low that directly impact the viability of local communities, access to educational facilities and infrastructure as well as supporting infrastructure are still limited. To improve the quality of Human Resources needs for various efforts from the Central Government, the provincial government and the Government of district/city because it directly related to life community quality. The need for Government support in the form of program activities trainings in order to be able to dig up potentials community as well as to improve the human resources in the border area region. Therefore, the ability to drive the Human Resources potential of the natural resources belonging managed, utilized and developed to fulfill these community's necessity.

Natural resources are the leading potential that could manage and utilize the maximum for the prosperity of local communities in the border area region. Development and natural resource are mapping and other flagship resource in order to be in utilizing for the region of the border so that it was able to encourage the of Community life quality around this border area, aims to develop the existing potentialities in this border area.

\section{Facility and Infrastructure of Road, Education, and Health}

Limitations and infrastructure barriers in the development of the border region should have a direct impact to the communities who live on the border. Infrastructure of road infrastructure are the main means of liaison between villages, districts and urban as the only access to the community in activities. In addition to the road also becomes the community's response to access education and health facilities are important with regard to the basic needs of society as this is an element that cannot separated by their lives. Therefore, the various facilty and infrastructure that should fulfilled by the Government to facilitate the community living the border area. The border area is vulnerable with many limitations and the question of whether its education, health, hampered due to the inability of the community to access such facilities.

\section{Conclusion and Suggestion}

First, the pattern of the border area management of the political ideology of Indonesia Republic and Papua New Guinea in Merauke Region have not done well because it happens to overlap of powers between sectors so that the management pattern of political ideology does not run as expected, low public knowledge against the rules and regulations. Applying in the border area so that the understanding of the people against the State boundary line is very low because direct impact to life community in the border area. The pattern of the district border security of management experience consists of various barriers to improve the quality of human and institutional resources, and limited facilities and infrastructure. In the form of facilities, means of road infrastructure has not been adequate, the vastness of the territory with the characteristics of the border that is difficult to reach the necessary means of supporting surveillance activity to support in the border area. Prosperity management pattern of Community border region experienced a failed human resources, access to education, health and infrastructure, inadequate basic skills level is still low, the economy of the community are traditional security and more prominent than on the welfare of the Community border area. Environmental management pattern regions border, are traditional, the exploitation of natural resources are in excessive (illegal logging box), (illegal trading), customary rights ownership culture over land and give recognition as well as protection settings of the customary rights of the Community border between Indonesia Republic-PNG in Merauke Region.

Second, analysis of restricting and supporting factors of the management of the border area between Indonesia Republic-PNG in Merauke Region indicates as follows:

1. Supporting Factor of human resources has a very important role moving all elements considering of border area in the development process. The potential of natural resources has not managed with good result of the capabilities and skills of the community still limited to manage natural resources, availability of infrastructure and facilities infrastructure became a solution to unlock the region border area between isolation and access the community in fulfilling local communities' necessity. Besides the security of the border, area became important to support the development process of border area Indonesia Republic -PNG in Merauke Region.

2. Restricting factors of limited human resources in managing the border area became the very best factors against the development process due to access to 
education and health is still low so as inhibit the increase in the human resources area of the border district. The lack of road facility and infrastructure becoming a barrier in the development process, both physical and nonphysical development so that directly impact public access will be education, health, infrastructure, settlements and the limited means of the basic necessities, electricity, clean water, and telecommunications.

The Customs and tradition of the local community to join in the development process there are also ownership (customary rights) that becomes restricting factor of community development process and the gap between the border areas with the city. The

Sugestions - According to the all explanation above and the research result as well as the conclusion then it suggests could suggested various thing relates to this research as follows:

1. The quality of human resources in the border area because the lack access to the community against the infrastructure supporting education and health due to levels of education, levels of low health, facility and infrastructure as the base is still lacking and low skills level.

2. Border area management pattern is still happening the gap between border areas resulting from the approach undertaken by the Central Government and local Government. The community is still highlighted security approach while the approach Welfare has not been optimally conducted in border area, this happens because the patterns are still welfare management to top down so that it is difficult in realizing.

3. The limited infrastructure and facilities became a border area of isolation due to the low accessibility towards the border area. To accelerate the development and availability of means of road infrastructure in order to be able to open access and encourage fluency activities community in order it can embody the progress of border areas.

4. The border area management Pattern are still top down due to ego sectorial ranging from the Central Government and local governments due to the overlap of power so that the development process whether it is a physical and non-physical development do not run effectively. lack of transportation facility and expensive accommodations affect the distribution of goods and services, the existence of real threat felt by local communities who live at the border and illegal logging activity and illicit drugs type's drugs. In the service of customs and Excise at Sota and Elikobel but are not yet effective and less availability of human resources, hence the need for the improvement of human resources quality so it is able to resolve the issue. Rampant theft of wood (illegal logging box) executed by the community who live around the border area. Rampant illegal exploitation resulting from logging box of forest natural resource, particularly the Community border, is very detrimental to the Government as well as other communities in the border areas of Indonesia Republic-PNG in Merauke Region.

There is no existence of the institutional management of the border area of integral to synergize entire sector related, because institutional owned still handled in ad hoc and handling areas of the border are temporary and partial as well as more dominated by a security approach so yet give optimum results.

\section{References}

1. Andrinof A. Chaniago. 2015. "RENCANA PEMBANGUNAN JANGKA MENENGAH NASIONAL 2015-2019.” In RENCANA PEMBANGUNAN JANGKA MENENGAH NASIONAL 2015-2019. https://doi.org/10.1017/CBO9781107415324.004.

2. Bappenas. 2006. "Poverty Reduction in Indonesia: A Brief Review of Facts, Efforst and Ways Forward." Forum on National Plans and PRSPs in East Asia.

3. Blanchard, Jean-Marc F. 2018. China's Maritime Silk Road Initiative and South Asia: A Political Economic Analysis of Its Purposes, Perils, and Promise. Palgrave Studies in Asia-Pacific Political Economy. https://doi.org/10.1007/978-981-10-52392 .

4. Brunet-Jailly, Emmanuel. 2017. Borderlands : Comparing Border Security in North America and Europe. Borderlands : Comparing Border Security in North America and Europe. https://doi.org/10.26530/oapen_578784.

5. Campbell, Ralph N., and George R. Terry. 2006. "Principles of Management." Industrial and Labor Relations Review. https://doi.org/10.2307/2518875. 
6. "Code of Conduct for Responsible Fisheries." 2012. In UNCLOS 1982 Commentary. https://doi.org/10.1163/9789004215627011.

7. Eben E. Siadari. 27AD. "Data BPS: Penduduk Asli Jadi Minoritas Di 5 Wilayah Papua." SATUHARAPAN.COM . 27AD.

8. Effendi, Usman. 2006. "Pembelajaran Publik : Suatu Upaya Pencegahan Dan Penanggulangan Korupsi." Portal Garuda.

9. Gunawan, Aditya Batara. 2017. "Civilian Control and Defense Policy in Indonesia's Nascent Democracy.” In Reforming Civil-Military Relations in New Democracies: Democratic Control and Military Effectiveness in Comparative Perspectives. https://doi.org/10.1007/978-3-319-53189-2_7.

10. Guo, Rongxing. 2015. Cross-Border Management: Theory, Method and Application. Cross-Border Management: Theory, Method and Application. https://doi.org/10.1007/978-3-662-45156-4.

11. Gutierrez, David G., and Oscar J. Martinez. 2006. "Border People: Life and Society in the U. S.Mexico Borderlands." The Western Historical Quarterly. https://doi.org/10.2307/970665.

12. Helliwell, John F. 2000. How Much Do National Borders Matter? The Canadian Journal of Economics / Revue Canadienne d'Economique.

13. Henry, O. 2012. "Henry Fayol (1841-1925): State Reform as Entrepreneurship ." Un Entrepreneur de Réforme de l'État : Henri Fayol (1841-1925).

14. Hersey, Paul, and Kenneth H. Blanchard. 1996. "Great Ideas: Revisiting the Life-Cycle Theory of Leadership." Training \& Development.

15. Indonesia, Presiden Republik. 2008. "UndangUndang Nomor 43 Tahun 2008 Tentang: Wilayah Negara." Undang-Undang Nomor 43 Tahun 2008 : Wilayah Negara.

16. Keban, Yeremias T. 2004. "Enam Dimensi Strategis Administrasi Publik: Konsep.” Teori Dan Isu, Yogyakarta: Gava Media. https://doi.org/10.1016/j.ijantimicag.2016.05.001.

17. Mann, Michael. 2013. The Sources of Social Power. The Sources of Social Power. https://doi.org/10.1017/cbo9781139236782.

18. Pratikno. 2007. “Governance Dan Krisis Teori Organisasi.” JKAP (Jurnal Kebijakan Dan Administrasi Publik).
19. PU, Kementerian. 2008. "PP No. 26 Tahun 2008 Tentang Rencana Tata Ruang Wilayah Nasional." Pemerintah Republik Indonesia. 2008.

20. Ricklefs, M. C. 2015. A History of Modern Indonesia since c. 1300. A History of Modern Indonesia since c. 1300. https://doi.org/10.1007/9781-349-22700-6.

21. Silalahi, Ulber. 2010. Metode Penelitian Sosial. PT Refika Aditama. https://doi.org/10.1055/s-20081040325 .

22. Sumarsono, Sonny. 2004. "Metode Riset Sumber Daya Manusia.” In Yogyakarta: Graha Ilmu, Edisi Pertama.

23. Tirtosudarmo, Riwanto. 2005. "The Orang Melayu and Orang Jawa in the "Lands Below the Winds." CRISE.

24. Ulfa, Nadlirotul, Desiana Rizka Fimmastuti, and Anisa Nur Nia Rahmah. 2018. "Hard and Soft Border Paradigm for Border Governance in Indonesia: A General Review." Politik Indonesia: Indonesian Political Science Review. https://doi.org/10.15294/jpi.v3i1.9396.

25. Ullman, Edward L., Stephen B. Jones, and S. Whittemore Boggs. 2006. "Boundary-Making: A Handbook for Statesmen, Treaty Editors, and Boundary Commissioners." Political Science Quarterly. https://doi.org/10.2307/2144171.

26. UN. 1982. United Nations Convention on the Law of the Sea Act. The International Journal of Marine and Coastal Law. https://doi.org/10.1163/15718089720491594.

27. UU No.27. 2007. UU No. 26 Tahun 2007 Tentang Penataan Ruang. Kementerian Pekerjaan Umum Dan Perumahan Rakyat.

28. Wahyuni, Putu Ika, IPG Ardhana, and I Nyoman Sunarta. 2008. "Evaluation of Ecotourism Development in Ngurah Rai Forest Park.” Ecotropic.

29. Wuryandari, Ganewati, R.R Emilia Yustiningrum, Nanto Sriyanto, and Athiqah Nur Alami. 2017. "Understanding Indonesia's Foreign Policy on Energy Security Issues.” In Foreign Policy and Energy Security Issues in Indonesia. https://doi.org/10.1007/978-981-10-4421-2_5. 